\title{
A Case of Pyoderma Gangrenosum in the Nasal Root Associated with Ulcerative Colitis
}

\author{
Ryo Kanamura $^{1)}$, Masakazu Goda ${ }^{1)}$, Seiichiro Kamimura ${ }^{2)}$, Hideyuki Nakagawa ${ }^{1)}$, \\ Jiro Udaka ${ }^{3)}$, Koichi Tamura ${ }^{1)}$ and Noriaki Takeda ${ }^{1)}$
}

We report herein on a case with pyoderma gangrenosum in the nasal root associated with ulcerative colitis. Pyoderma gangrenosum is characterized by progressive skin necrosis and is often associated with chronic bowel inflammatory diseases such as ulcerative colitis and Crohn's disease. Although it bears a clinical resemblance to self-destructive abscesses or bacterial infection of the soft tissues, no bacteria and non-effects of antimicrobial agents were observed and the drainage of the abscess and debridement of necrotic tissue is contraindicated in patients with pyoderma gangrenosum. The treatment of the underlying disease is also effective for the treatment of pyoderma gangrenosum. In the present case, a steroid and mesalazine were effective for both the pyoderma gangrenosum and ulcerative colitis.

Keywords : pyoderma gangrenosum, ulcerative colitis, progressive skin necrosis, roof of nose, skin ulcer

\section{References}

1）田村 真, 中村匡男, 深沢正之, 他 : 硬膜外カテーテル穿 刺部に発生した壊疽性膿皮症の 1 例. 日臨麻会誌 27 : $55^{-}$ 60, 2007.

2）佐々木寛文, 内野 基, 坂東俊宏, 他 : 手術創に壊疽性膿 皮症を合併した潰瘍性大腸炎の 1 例. 日臨外会誌 71：29022906, 2010.

3) Brooklyn T, Dunnill G and Probert C : Diagnosis and treatment of pyonderma gangrenosum. BMJ 333: 181-184, 2006.

4) Crowson AN, Mihm MC Jr and Magro C : Pyoderma gangrenosum: a review. J Cutan Pathol 30: 97-107, 2003.

5）柳川洋一，西紘一郎，岩崎純也：壊疽性軟部組織感染症と の鑑別に苦慮した壊疽性膿皮症の 1 例. 日救急医会誌 19: 1095-1100, 2008.
6) Weedon D : PYODERMA GANGRENOSUM. SKIN Pathology 2nd edition. pp 251-252, Churchill Livingstone, Edinburgh, 2002.

7）加藤晴久：壊疽性膿皮症の 1 例. 皮膚 38：352-355, 1996.

8）宗本義則, 笠原善郎, 三井 毅, 他：壊疽性膿皮症を合併 した潰瘍性大腸炎の 2 例. 日臨外会誌 59: 2621-2624, 1998.

9）柳澤和彦, 山本雅由, 谷澤伸次, 他: タクロリムス軟膏が 著効した壊疽性膿皮症の 1 例. 日消外会誌 42: 122-126, 2009.

10）牧浦宗彦, 清水義徳, 鈴木加余子, 他 : 大動脈炎症候群に 合併した壊疽性膿皮症の 1 例. 皮膚 43: 222-225, 2001.

11）山守暢子, 成田 洋, 吉冨裕久, 他 : 壊疽性膿皮症を合併 した潰瘍性大腸炎の 1 例. 日臨外医会誌 53：1648-1653, 1992.
1) Department of Otolaryngology, University of Tokushima School of Medicine

2) Department of Otolaryngology, Tokushima Prefectural Central Hospital

3) Udaka ENT Clinic
Corresponding Author Address : Ryo Kanamura r.kanamura@gmail.com 

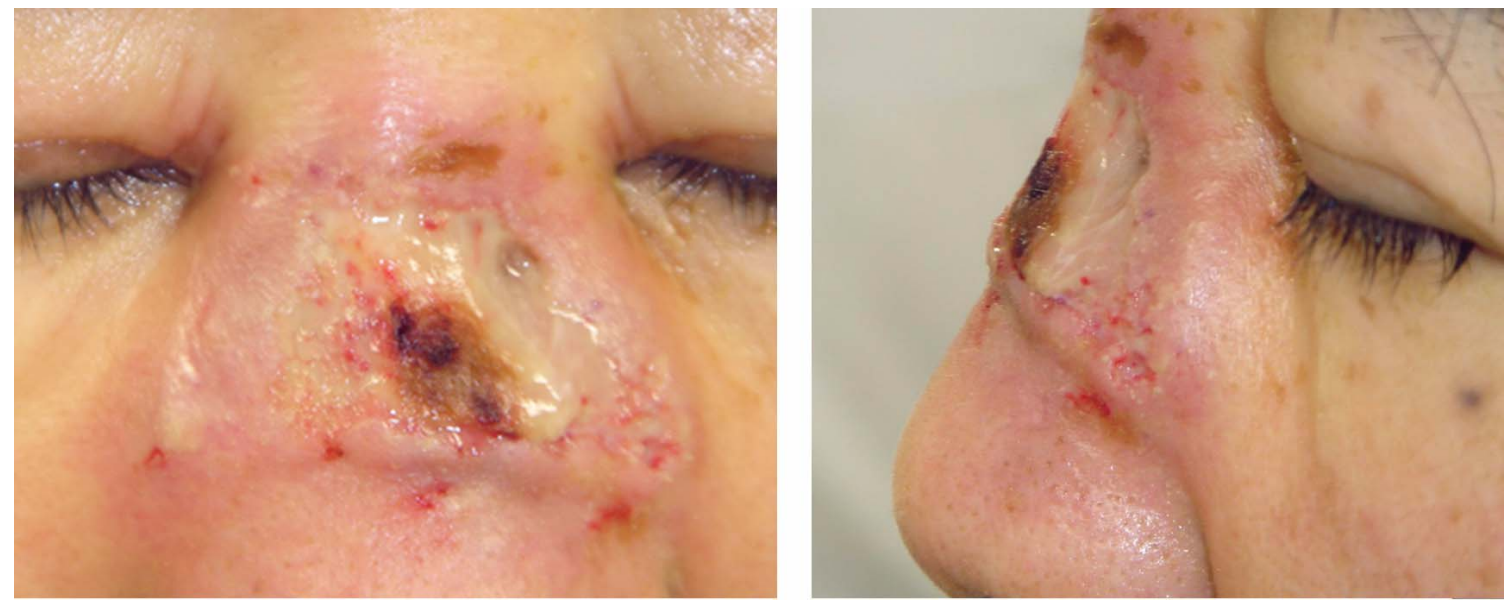

An uncreative lesion in the root of the nose in a 51-year-old female patient.

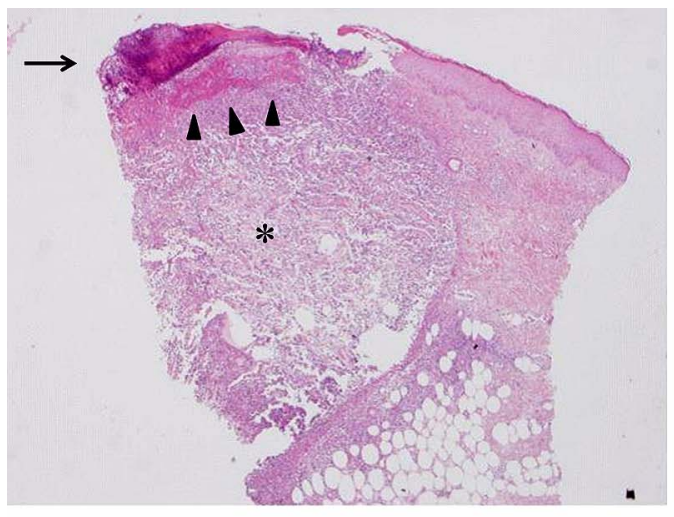

a

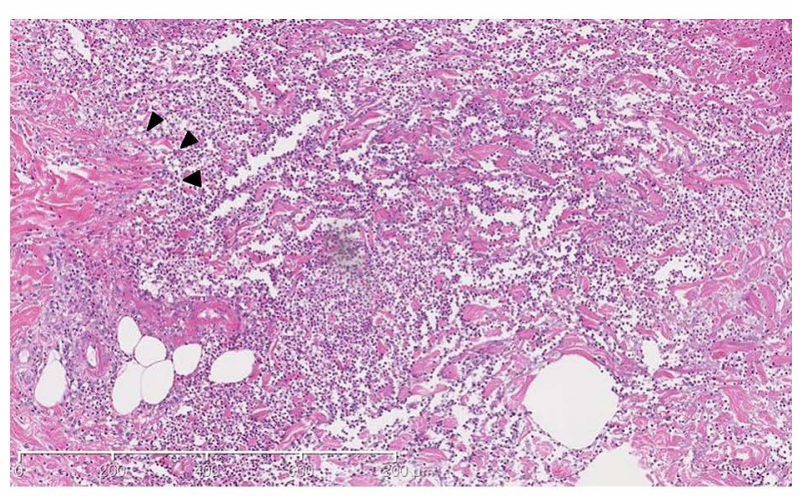

b

Histopathologic examination from skin of the lower leg shows that the abscess invades deep into the skin (*) with accompanying necrosis (arrow) (a: H\&E; original magnification X20). Infiltration of a neutrophil and fibrin formation (arrow head) are observed around the abscess (b: H\&E; original magnification X100). 